J. Akademika Kim. 4(4): 181-188, November 2015

ISSN 2302-6030 (p), 2477-5185 (e)

\title{
PEMANFAATAN BUAH MENGKUDU (Morinda citrifolia L.) SEBAGAI ADSORBENUNTUK MENINGKATKAN MUTU MINYAK JELANTAH
}

\section{Utilization of Noni (Morinda citrifolia L.) Fruit as Adsorbent to Improve the Quality of Used Cooking Oil}

\author{
* I Nengah Juliana, Siang Tandi Gonggo, dan Irwan Said \\ Pendidikan Kimia/FKIP - Universitas Tadulako, Palu - Indonesia 94118 \\ Received 07 September 2015, Revised 07 October 2015, Accepted 06 November 2015
}

\begin{abstract}
The aim of this study is to lower the value quality parameters of used cooking oil to reach the national industry standards using adsorbent of noni (morinda citrifolia L.) fruit as well as to determine the optimum concentration (\% w/w) of noni in increasing quality of used cooking oil. The parameters in this study are the water content, free fatty acids, colour and density. The method used to determine the water content and free fatty acid levels were the gravimetric method and acid-base titration, while determination of the colour and density used UV-Vis spectrophotometer and pycnometer. The concentration of noni adsorbent in the oil refining process varied ie $12 \%, 15 \%, 18 \%, 21 \%$, and $24 \%$. The results showed that the water content, free fatty acids, and the density decrease with an increase in adsorbent. The oil colourwas brighter with increasing noni fruit adsorbent used. The study showed that the noni fruit adsorbent can lower the value quality parameters of used cooking oil, and only the density from the four parameters did not meet ISO standard. The concentration weight per weight (\% w/w) optimum noni fruit was $24 \%$.
\end{abstract}

Keywords: Used cooking oil, noni (Morinda citrifolia L.), Water Content, Free Fatty Acid, colour.

\section{Pendahuluan}

Minyak goreng merupakan salah satu kebutuhan pokok manusia sebagai alat pengolah bahan-bahan makanan. Minyak goreng berfungsi sebagai penghantar panas, penambah rasa gurih, dan penambah nilai kalori bahan pangan (Irwan, dkk., 2010). Minyak dan lemak mengandung komponen utama berupa trigliserida yang merupakan ester dari asam lemak dan gliserol (Wijayanti, 2009). Minyak yang dipakai berulang-ulang untuk menggoreng kualitasnya turun dan bila digunakan dapat mempengaruhi kesehatan. Kualitas minyak goreng bekas ini antara lain dilihat dari warna yang menjadi lebih gelap dan tidak jernih, kadar asam lemak bebas dan bilangan peroksida yang tinggi, aroma kurang enak dan kental (Kusumastuti, 2004).

Trigliserida merupakan gliserol yang berikatan dengan 3 asam lemak. Ketiga

*Correspondence:

I Nengah Juliana

Program Studi Pendidikan Kimia, Fakultas Keguruan dan

Ilmu Pendidikan, Universitas Tadulako

email: julianainengah@gmail.com

Published by Universitas Tadulako 2015

asam lemak yang berikatan dengan gliserol dapat sama maupun berbeda. Rumus kimia trigliserida seperti pada Gambar 1, dimana R1, R2, R3 adalah rantai alkil (Wibowo, 2009).

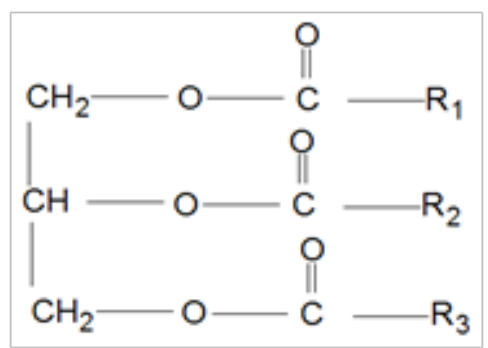

Gambar 1 Struktur dasar kimia trigliserida

Minyak kelapa sawit terutama mengandung asam palmitat (C 16:0) pada fraksi stearinnya dan asam oleat (C 18:1) pada fraksi oleinnya. Komposisi asam lemak dari kelapa sawit dapat dilihat pada Tabel 1 (Febriansyah, 2007).

Tabel 1 Komposisi asam lemak pada minyak kelapa sawit. 


\begin{tabular}{|c|c|}
\hline Asam Lemak & Jumlah (\%) \\
\hline C $12: 0$ & $<12$ \\
\hline C $14: 0$ & $0,5-5,9$ \\
\hline C $16: 0$ & $32-59$ \\
\hline C $16: 1$ & $<0,6$ \\
\hline C $18: 0$ & $1,5-8,0$ \\
\hline C $18: 1$ & $27-52$ \\
\hline C $18: 2$ & $5,0-14$ \\
\hline C $18: 3$ & $<1,5$ \\
\hline C $20: 0$ & $<1,0$ \\
\hline C $20: 1$ & - \\
\hline C $22: 0$ & - \\
\hline
\end{tabular}

Minyak goreng bekas mudah diperoleh dari industri seperti penggunaan domestik dan restoran (Gashaw \& Teshita, 2014). Limbah minyak goreng selalu menjadi masalah di lingkungan pabrik-pabrik makanan di Batu Pahat, Johor, Malaysia (Abdullah, dkk., 2013). Indikator kerusakan minyak antara lain adalah angka peroksida dan asam lemak bebas. Angka peroksida menunjukkan banyaknya kandungan peroksida di dalam minyak akibat proses oksidasi. Asam lemak bebas menunjukkan sejumlah asam lemak bebas yang dikandung oleh minyak yang rusak, terutama karena peristiwa oksidasi dan hidrolisis (Gunawan, dkk., 2003). Kerusakan yang utama pada minyak yang dapat diamati secara visual adalah timbulnya bau dan rasa tengik yang disebabkan oleh autooksidasi radikal asam lemak tidak jenuh dalam minyak dan peningkatan bilangan peroksida dan thiobarbituric acid (TBA), serta dihasilkan senyawa aldehida dan keton (Ahmadi, 2009).

Sehubungan dengan banyaknya minyak goreng bekas dari sisa industri maupun rumah tangga dalam jumlah tinggi dan menyadari adanya bahaya konsumsi minyak goreng bekas, maka perlu dilakukan upaya-upaya untuk memanfaatkan minyak goreng bekas tersebut agar tidak terbuang dan mencemari lingkungan. Salah satu alternatif cara peningkatan kualitas minyak goreng bekas adalah dengan adsorpsi menggunakan adsorben sehingga mutu minyak dapat dipertahankan (Wijayanti, dkk., 2012).

Daur ulang minyak goreng bekas dapat menggunakan adsorben, seperti silika gel, magnesium oksida, gel aluminium hidroksida dan tanah liat diaktifkan (Wannahari \& Nordin, 2012). Penelitian pengolahan minyak goreng bekas telah banyak dilakukan dan banyak juga yang menghasilkan temuan dalam bentuk paten. Proses pengolahan minyak goreng bekas telah dilakukan oleh (Wulyoadi \& Kaseno, 2004) dimana minyak goreng bekas dimurnikan dengan membran. Hasil yang diperoleh menunjukkan bahwa membran dengan ukuran pori 0,001 paling efektif dalam memurnikan minyak jelantah (Widayat, 2007).

Minyak yang bermutu baik dapat diperoleh dengan cara minyak kasar harus dimurnikan dari bahan-bahan atau kotoran yang terdapat didalamnya. Cara-cara pemurnian dilakukan dalam beberapa tahap yaitu pengendapan (settling) dan pemisahan gumi (degumming), netralisasi dengan alkali, pemucatan (bleching), penghilangan bau (deodorisasi) lemak (Winarno, 1995).

Kandungan kimia penting pada sari buah mengkudu adalah asam lemak yang meliputi: asam kaproat, kaprilat, asam palmitat, asam stearat dan asam oleat. Kandungan nutrisi yang terkandung dalam buah mengkudu adalah protein, mineral Se, vitamin $\mathrm{C}$ dan asam lemak rantai pendek yang menyebabkan bau yang menyengat. Menurut (Winarti, 2008) kadar vitamin C pada buah mengkudu yaitu 12,24\%. Buah mengkudu menghasilkan sederatan antioksidan diantaranya: scopoletin, nitric oxide, vitamin C dan vitamin A (Bijanti, 2008).

Antioksidan adalah subtansi yang dapat menunda, mencegah, menghilangkan kerusakan oksidatif pada molekul target, seperti lemak dan protein. Antioksidan merupakan suatu inhibitor dari proses oksidasi bahkan pada konsentrasi yang relatif kecil, dan memiliki peran fisiologis yang beragam dalam tubuh. Antioksidan yang digunakan dalam sistem biologis berfungsi untuk mengatur kadar radikal bebas agar kerusakan pada molekul penting dari tubuh tidak terjadi dan tercipta sistem perbaikan yang diperlukan untuk mempertahankan kelangsungan hidup dari sel (Purwaningsih, 2012). Antioksidan dapat bereaksi cepat dengan radikal sehingga berfungsi sebagai penjerat (trap) radikal. Perubahan sifat fisik dan kimia antioksidan tidak hanya mengakibatkan kerusakan nilai gizi tetapi juga warna dan rasa minyak (Handoko, dkk., 2009).

Menurut Irwan, dkk., (2010) bahwa 
sari mengkudu dapat memperbaiki kualitas minyak jelantah agar dapat digunakan kembali sebagai media penggoreng. Berdasarkan hasil penelitian diketahui bahwa asam lemak bebas turun $24,68 \%$ sedangkan bilangan peroksida turun $46,06 \%$.

Sarungu (2010) memanfaatkan sari buah mengkudu untuk penjernihan minyak jelantah. Hasil yang diperoleh yaitu sebelum penjernihan diperoleh kadar air 0,2\%, kadar free fatty acid (FFA) $0,31 \%$, kadar peroksida $31,926 \mathrm{meq}$ O2 / 1000 gram minyak dan kadar iod 40,275. Hasil setelah penjernihan yaitu $0,4 \%$, kadar free fatty acid (FFA) $0,23 \%$, kadar peroksida 3 meq O2 /1000 gram minyak dan angka iod 41,48.

Penelitian yang dilakukan oleh Barau (2014) menggunakan adsorben dari buah mengkudu sebagai pengadsorbsi minyak jelantah menunjukan bahwa kualitas minyak jelantah tanpa adsorben mengandung kadar asam lemak bebas sebesar $0,6 \%$, bilangan peroksida sebesar 30 meq.O2/kg, kadar air sebesar 10\%, dan kadar kotoran sebesar 1,74\%. Setelah dilakukan adsorbsi dengan variasi konsentrasi 5\%, 10\% dan 15\% (berat adsorben $/ 100 \mathrm{~mL}$ minyak jelantah), ternyata adsorben yang memberikan peningkatan kualitas minyak yang paling baik terdapat pada konsentrasi $15 \%$. Kadar asam lemak bebas, bilangan peroksida, kadar air dan kadar kotoran dengan $15 \%$ adsorben mengkudu masing-masing yaitu 0,2\%, 2 meq.O2/kg, 0,02\% dan 0,09\%. Hal ini menunjukan kualitas minyak jelantah menjadi lebih baik setelah penambahan mengkudu yang berfungsi sebagai adsorben. Namun masih ada kemungkinan konsentrasi optimum penambahan adsorben buah mengkudu yaitu antara $10 \%-15 \%$ dan di atas $15 \%$.

Banyaknya limbah minyak jelantah yang dihasilkan oleh industri kecil, menengah, dan industri besar perlu dilakukan penelitian tentang pemanfaatan buah mengkudu (Morinda citrifolia L.) sebagai adsorben untuk meningkatkan mutu minyak jelantah. Adsorben dari buah mengkudu diharapkan dapat meningkatkan mutu minyak jelantah. Mutu minyak yang meningkat dapat dilihat dari beberapa perubahan nilai parameter yang digunakan yaitu berat jenis, warna, kadar air, dan bilangan asamnya. Tujuan penelitian ini yaitu menurunkan nilai parameter mutu minyak jelantah untuk mencapai standar nasional industri dengan menggunakan adsorben dari buah mengkudu (Morinda citrifolia L.) dan menentukan konsentrasi berat per berat $(\% \mathrm{~b} / \mathrm{b})$ optimum buah mengkudu dalam peningkatan mutu minyak jelantah.

\section{Metode}

\section{Alat dan Bahan}

Peralatan yang digunakan pada penelitian ini yaitu gelas kimia, gelas ukur, buret, statif dan klem, pipet tetes, erlenmeyer, blender, labu ukur, pipet ukur, kertas saring, pisau, termometer, pengaduk listrik, penangas listrik, piknometer, neraca digital, oven, desikator, spektrofotometer UV-Vis, krusibel, magnetic stirrer, ayakan 70 mesh dan stopwatch. Bahanbahan yang digunakan dalam penelitian ini yaitu minyak jelantah, minyak goreng baru, buah mengkudu, etanol 95\% dari Ajax chemicals, indikator PP, $\mathrm{NaOH}$ dari Merk, $\mathrm{H}_{2} \mathrm{C}_{2} \mathrm{O}_{4}$ dari Merk, dan aquades.

\section{Preparasi buab mengkudu}

Buah mengkudu yang mengkal dibersihkan terlebih dahulu, lalu diiris tipis-tipis. Buah mengkudu yang telah diiris tipis-tipis dianginanginkan pada suhu ruang sampai kering, lalu diblender sehingga menjadi serbuk halus. Selanjutnya serbuk halus yang didapat diayak dengan menggunakan ayakan 70 mesh.

\section{Proses pemurnian minyak \\ Proses penghilangan bumbu (despicing)}

Despicing merupakan proses pengendapan dan pemisahan kotoran akibat bumbu dan kotoran dari bahan pangan yang bertujuan menghilangkan partikel halus bersuspensi atau membentuk koloid seperti protein, karbohidrat, garam, gula dan bumbu rempah-rempah yang digunakan menggoreng bahan pangan tanpa mengurangi jumlah asam lemak bebas dalam minyak. Proses despicing ini dilakukan dalam tempat logam atau kaca tahan panas agar proses despicing berlangsung dengan baik, bumbu dan semua kotoran yang ada dalam minyak jelantah akan mengendap dan minyak lebih mudah dipisahkan dari pengotor-pengotornya (Barau, 2014).

\section{Pemucatan (Bleaching) minyak jelantah.}

Sebanyak $100 \mathrm{~mL}$ minyak jelantah dipanaskan hingga mencapai suhu $90^{\circ} \mathrm{C}$, setelah itu ditambahkan serbuk mengkudu dengan variasi konsentrasinya yaitu $12 \%$, 
15\%, 18\%, 21\% dan 24\% (\%b/b), kemudian diaduk dengan kecepatan $100 \mathrm{rpm}$ selama 60 menit. Lalu disaring untuk diambil filtrat atau minyak yang telah diadsorbsi.

\section{Penentuan kadar asam lemak bebas}

Ditimbang 3 gram sampel ke dalam erlenmeyer $100 \mathrm{~mL}$. Ditambahkan $5 \mathrm{~mL}$ etanol 95\% dan dipanaskan sampai mendidih ( \pm 10 menit) dalam penangas air sambil diaduk, kemudian setelah dingin ditambahkan 2 tetes indikator fenolftalein dan dititrasi dengan larutan standar $\mathrm{NaOH} 0,0094 \mathrm{~N}$ (yang sebelumnya telah distandarisasi dengan larutan $\mathrm{H} 2 \mathrm{C} 2 \mathrm{O} 40,1 \mathrm{~N}$ ) hingga warna merah muda tetap (tidak berubah selama 15 detik). Dilakukan penetapan blanko. Kadar asam lemak bebas dihitung sebagai asam laurat dinyatakan sebagai persen asam lemak sesuai persamaan (1) (Barau, 2014).

Kadar FFA $(\%)=\frac{\mathrm{V} \times \mathrm{N} \times \mathrm{Mr} \text { asam laurat }}{\mathrm{m} \times 1000} \times 100 \%$

$\mathrm{V}=\mathrm{V}_{\text {titran untuk sampel }}-\mathrm{V}_{\mathrm{NaOH} \text { untuk blanko }}$

\section{Analisis berat jenis}

Sampel dimasukkan ke dalam piknometer kemudian ditutup dan direndam dalam air suhu 25 oC selama 30 menit. Dikeringkan bagian luar piknometer dan ditimbang persamaan (2) (Muallifah, 2009).

Berat jenis $=\frac{\text { (bobot piknometer dan minyak)-(bobotpiknometer kosong) }}{\text { Volumeair pada } 25^{\circ} \mathrm{CmL}}$

\section{Penentuan kadar air}

Penentuan kadar air menggunakan oven. Krusibel dicuci bersih dan dikeringkan lalu dipanaskan dalam oven pada suhu $105^{\circ} \mathrm{C}$ selama 1 jam. Selanjutnya didinginkan dalam desikator selama $1 / 2$ jam. Kemudian krusibel ditimbang dan dicatat bobotnya. Perlakuan ini diulang sampai diperoleh bobot yang tetap. Selanjutnya sampel minyak jelantah dimasukan ke dalam krusibel sebanyak 1 gram dan dipanaskan lagi pada oven dengan suhu $105^{\circ} \mathrm{C}$ selama 1 jam, lalu didinginkan dalam desikator selama $1 \frac{1}{2}$ jam. Kadar air dinyatakan sebagai $\%$ (b/b) (Barau, 2014):

$$
\text { Kadar air }=\frac{m_{1}-m_{2}}{m_{1}} \times 100 \%
$$

Keterangan:

$\mathrm{m} 1$ = bobot sampel sebelum dipanaskan (gram)

$\mathrm{m} 2$ = bobot sampel setelah dipanaskan (gram)

\section{Warna}

Warna minyak diukur dengan menggunakan spektrofotometer UV-Vis. Sampel minyak dimasukkan ke dalam kuvet. Setelah itu, diukur absorbansinya pada panjang gelombang 470 $n m$ dengan menggunakan sampel minyak awal sebagai blanko (Paramitha, 2012).

\section{Hasil dan Pembahasan \\ Asam lemak bebas}

Penentuan kadar asam lemak bebas menggunakan metode titrasi asam basa dan hasilnya dihitung dengan menggunakan persamaan (1) diperoleh kadar asam lemak bebas minyak jelantah dan minyak hasil pemurnian yang dapat dilihat pada Tabel 2 .

\section{Kadar air}

Penentuan kadar air menggunakan metode gravimetri dan dengan menggunakan persamaan (3) diperoleh kadar air minyak jelantah dan minyak hasil pemurnian yang dapat dilihat pada Tabel 2 .

\section{Warna}

Penentuan absorbansi minyak menggunakan spektrofotometer UV-Vis, dimana pengukurannya dilakukan pada panjang gelombang $470 \mathrm{~nm}$ sehingga diperoleh absorbansi minyak jelantah dan minyak hasil pemurnian yang dapat dilihat pada Tabel 2 . 
Tabel 2 Kadar asam lemak bebas, kadar air, dan absorbansi minyak jelantah dan minyak hasil pemurnian

\begin{tabular}{|c|l|c|c|c|}
\hline No & Minyak jelantah & $\begin{array}{c}\text { Kadar FFA (\%) } \\
\text { rata-rata }\end{array}$ & $\begin{array}{c}\text { Kadar air (\%) } \\
\text { rata-rata }\end{array}$ & $\begin{array}{c}\text { Absorbansi } \\
\text { rata-rata }\end{array}$ \\
\hline 1 & Tanpa adsorben & 0,4011 & 1,4292 & 0,9975 \\
\hline 2 & Adsorben $12 \%$ & 0,1128 & 0,2291 & 0,7225 \\
\hline 3 & Adsorben 15\% & 0,0909 & 0,2198 & 0,7120 \\
\hline 4 & Adsorben 18\% & 0,1034 & 0,2196 & 0,7005 \\
\hline 5 & Adsorben 21\% & 0,0721 & 0,2193 & 0,6945 \\
\hline 6 & Adsorben 24\% & 0,0564 & 0,2190 & 0,6830 \\
\hline
\end{tabular}

\section{Berat jenis}

Penentuan berat jenis minyak ditentukan dengan menggunakan piknometer. Pengukuran berat jenis ini dapat digunakan untuk mengukur kemurnian minyak (Muallifah, 2009). Data hasil penelitian berat jenis minyak jelantah dan minyak hasil pemurnian dengan menggunakan persamaan (2) diperoleh hasil pada Tabel 3.

Tabel 3 Berat jenis minyak goreng baru, minyak jelantah dan minyak hasil pemurnian

\begin{tabular}{|c|c|c|}
\hline No & Minyak & $\begin{array}{c}\text { Berat jenis rata-rata } \\
(\mathrm{g} / \mathrm{mL})\end{array}$ \\
\hline 1 & Minyak baru & 0,9093 \\
\hline 2 & Tanpa adsorben & 1,8900 \\
\hline 3 & Adsorben $12 \%$ & 1,8896 \\
\hline 4 & Adsorben $15 \%$ & 1,8896 \\
\hline 5 & Adsorben $18 \%$ & 1,8868 \\
\hline 6 & Adsorben $21 \%$ & 1,8860 \\
\hline 7 & Adsorben $24 \%$ & 1,8836 \\
\hline
\end{tabular}

\section{Pembahasan \\ Asam Lemak Bebas}

Asam lemak bebas merupakan hasil hidrolisis dari trigliserida. Pada saat minyak digunakan merupakan awal proses asam lemak bebas dihasilkan melalui proses pemecahan oksidasi. Minyak goreng yang digunakan dalam proses penggorengan sejumlah besar akan dipanaskan pada suhu mencapai 162$1960 \mathrm{C}$ dengan kondisi bahan pangan yang terendam dan digunakan secara kontinu akan menghasilkan asam lemak bebas pada minyak goreng tersebut (Paramitha, 2012). Angka asam dinyatakan sebagai jumlah miligram $\mathrm{KOH}$ yang diperlukan untuk menetralkan asam lemak bebas dalam satu gram minyak. Angka asam yang besar menunjukkan asam lemak bebas yang besar (Abdullah, 2007). Adanya asam lemak bebas meskipun jumlahnya kecil dapat mengakibatkan rasa minyak goreng tidak lezat, hal ini berlaku juga untuk asam lemak yang tidak mudah menguap yaitu dengan jumlah atom $\mathrm{C}$ lebih besar dari 14 (Winarni, dkk., 2010).

Berdasarkan Tabel 2 dapat dilihat bahwa terjadi penurunan kadar asam lemak bebas pada konsentrasi $0-15 \%$ adsorben buah mengkudu. Namun, setelah pada konsentrasi $18 \%$ kadar asam lemak bebas meningkat kembali. Selanjutnya pada konsentrasi $21 \%$ dan $24 \%$ kadar asam lemak bebas menurun. Sehingga diperoleh kondisi adsorben buah mengkudu yang optimum ditambahkan ke dalam minyak jelantah adalah pada konsentrasi $24 \%$. Kadar asam lemak bebas minyak hasil pemurnian telah mencapai ambang batas persentase asam lemak bebas yang ditetapkan oleh SNI 37411995 yang berisi syarat kandungan asam lemak bebas maksimal adalah 0,30\%. Kadar asam lemak bebas minyak menurun disebabkan oleh:

1. Adanya vitamin $\mathrm{C}$ yang terkandung dalam buah mengkudu yang mampu menetralisir atau menstabilkan senyawa asam lemak bebas yang terkandung dalam minyak jelantah (Sarungu, 2010).

2. Adanya proses adsorbsi fisik pada asorben buah mengkudu, karena adsorben buah mengkudu memiliki luas permukaan dan pori-pori yang besar, sehingga mengikat dan menyerap senyawa asam lemak bebas pada permukaannnya. Kandungan asam lemak yang besar menunjukkan mutu suatu minyak rendah dan tidak baik untuk digunakan kembali (Aisyah, dkk., 2010) .

\section{Kadar air}

Keberadaan air dalam minyak goreng menyebabkan adanya reaksi hidrolisis yang menyebabkan terurainya bentuk trigliserida menjadi asam lemak bebas yang dapat bereaksi lebih lanjut menjadi aldehid dan keton, yang merupakan indikasi terjadinya rancidity (tengik) pada minyak goreng. Air dalam minyak goreng berada dalam bentuk koloid yang distabilkan adanya protein dalam minyak goreng. Sehingga untuk meningkatkan kualitas minyak goreng maka keberadaan air harus direduksi seminim mungkin. Pelepasan molekul air dari minyak goreng dapat pula dilakukan dengan pemanasan akan tetapi perlakuan termal terhadap minyak goreng dapat menyebabkan terputusnya ikatan trigliserida.

Berdasarkan Tabel 2 dapat dilihat bahwa terjadi penurunan kadar air dari konsentrasi $0-24 \%$ adsorben buah mengkudu yaitu $1,4292 \%, \quad 0,2291 \%, \quad 0,2198 \%, \quad 0,2196 \%$, $0,2193 \%$ dan 0,2190\%. Kadar air minyak 
hasil pemurnian telah mencapai ambang batas persentase kadar air yang ditetapkan oleh SNI 3741-1995 yang berisi syarat kandungan air maksimal adalah 0,3\%. Menurunnya kadar air pada minyak jelantah disebabkan oleh proses adsorpsi fisik antara molekul $\mathrm{H}_{2} \mathrm{O}$ dengan adsorben dikarenakan adanya perbedaan energi potensial antara permukaan adsorben dan zat yang diserap. Banyaknya luas permukaan adsorben buah mengkudu yang berinteraksi dengan pengotor, maka semakin banyak pula pengotor yang terjebak dalam pori-pori adsorben buah mengkudu (Muallifah, 2009).

Kadar air dalam minyak dapat dikurangi dengan adanya proses pemurnian, yang meliputi proses despicing, netralisasi dan bleaching. Proses despicing, bertujuan untuk memisahkan fraksi-fraksi berat dalam minyak. Fraksi-fraksi berat tersebut akan larut dalam air dan ikut mengendap di bawah permukaan air, sehingga diperoleh minyak bebas bumbu. Larutnya fraksi-fraksi berat tersebut karena sifatnya polar, karena itu kadar air dalam minyak juga ikut berkurang. Proses netralisasi, bertujuan untuk memisahkan asam lemak bebas dengan mereaksikan minyak dengan $\mathrm{NaOH}$, yang menghasilkan sabun dan air. Sabun yang terbentuk dapat membantu pemisahan kotoran, salah satunya air dalam minyak. Proses bleaching adalah mencampurkan adsorben buah mengkudu dengan minyak. Kemampuan buah mengkudu sebagai adsorben tersebut, dikarenakan struktur kimia permukaan, susunan pori-pori dan luas permukaan adsorpsi, serta komposisi kimia permukaan yang ada dalam buah mengkudu (Muallifah, 2009).

\section{Warna}

Warna telah dijadikan sebagai indek kualitas minyak selama bertahun-tahun. Metode pengujian warna dapat dilakukan dengan menggunakan Lovibond dan spektrofotometer. Terdapat perbedaan antara kedua metode penentuan warna minyak ini metode Lovibond bersifat subjektif sedangkan penentuan secara spektrofotometer bersifat objektif. Pengukuran dengan menggunakan spektrofotometer dilakukan pada panjang gelombang 470 nm (Paramitha, 2012). Absorbansi yang semakin besar pada panjang gelombang ini mengindikasikan warna minyak semakin gelap. Hal ini berarti semakin banyak poduk-produk hasil degradasi minyak (Febriansyah, 2007).

Berdasarkan Tabel 2 dapat dilihat bahwa terjadi penurunan absorbansi dari konsentrasi $0-24 \%$ adsorben buah mengkudu yaitu 0,9975 , $0,7225,0,7120,0,7005,0,6945$, dan 0,6830 .
Semakin besar nilai absorbansi minyak goreng maka semakin gelap warna minyak tersebut. Sebaliknya semakin kecil nilai absorbansi minyak goreng maka semakin terang warna minyak tersebut. Menurunnya nilai absorbansi minyak disebabkan oleh proses absorbsi fisik oleh situs-situs aktif dalam karbon, seperti susunan pori-pori dan luas permukaan adsorben buah mengkudu. Proses adsorbsi fisik ini terjadi karena adanya perbedaan energi potensial antara permukaan adsorben dan adsorbat, yang melibatkan gaya fisika. Adsorpsi fisika melibatkan gaya antarmolekuler (gaya Van der Walls) dan bersifat reversible. Pada proses terserapnya oksigen, air, alkoksil, peroksida di dinding atau permukaan adsorben buah mengkudu, ini dapat terjadi adsorpsi secara fisika karena setiap partikel-partikel adsorbat yang mendekati permukaan adsorben melalui gaya Van der Waals (Muallifah, 2009).

Hasil penelitian menunjukkan bahwa semakin banyak adsorben yang digunakan maka semakin kecil pula absorbansi minyak goreng. Hal ini disebabkan fraksi-fraksi berat dalam minyak seperti protein, karbohidrat, garam, gula, bumbu dan rempah-rempah berkurang telah diabsorbsi oleh adsorben buah mengkudu sehingga warna minyak semakin cerah.

Berat jenis

Berat jenis merupakan salah satu kriteria penting dalam menentukan mutu dan kemurnian minyak. Nilai berat jenis minyak didefinisikan sebagai perbandingan antara berat minyak dengan berat air pada volume air yang sama dengan volume minyak pada yang sama pula. Berat jenis sering dihubungkan dengan fraksi berat komponen-komponen yang terkandung di dalamnya. Semakin besar fraksi berat yang terkandung dalam minyak, maka semakin besar pula nilai densitasnya. Berat jenis dapat digunakan untuk semua minyak dan lemak yang dicairkan, alat yang digunakan untuk penentuan ini ialah piknometer (Muallifah, 2009).

Berdasarkan Tabel 3 dapat dilihat bahwa terjadi penurunan berat jenis dari konsentrasi $0-24 \%$ adsorben buah mengkudu yaitu 1,8900 $\mathrm{g} / \mathrm{mL}, 1,8896 \mathrm{~g} / \mathrm{mL}, 1,8896 \mathrm{~g} / \mathrm{mL}, 1,8868 \mathrm{~g} /$ $\mathrm{mL}, 1,8860 \mathrm{~g} / \mathrm{mL}, 1,8836 \mathrm{~g} / \mathrm{mL}$. Sedangkan berat jenis minyak goreng baru yaitu 0,9093 $\mathrm{g} / \mathrm{mL}$. Berat jenis minyak hasil pemurnian belum mencapai ambang batas persentase berat jenis yang ditetapkan oleh SNI 3741-1995 yang berisi syarat berat jenis maksimal adalah $0,900 \mathrm{~g} / \mathrm{mL}$. Hal ini disebabkan oleh masih adanya fraksi-fraksi berat dalam minyak seperti protein, karbohidrat, garam, gula, bumbu dan 
rempah-rempah berkurang telah diabsorbsi oleh adsorben buah mengkudu. Menurut Muallifah (2009) berat jenis dihubungkan dengan fraksi berat komponen-komponen yang terkandung di dalam minyak, semakin besar fraksi berat yang terkandung dalam minyak, maka semakin besar pula nilai berat jenisnya.

Menurunnya nilai berat jenis minyak disebabkan oleh proses absorbsi fisik oleh situssitus aktif dalam adsorben buah mengkudu, seperti susunan pori-pori dan luas permukaan. Proses adsorbsi fisik ini terjadi karena adanya perbedaan energi potensial antara permukaan adsorben dan adsorbat, yang melibatkan gaya fisika. Adsorpsi fisika melibatkan gaya antarmolekuler (gaya Van der Walls) dan bersifat reversible. Pada proses terserapnya oksigen, air, alkoksil, peroksida, di dinding atau permukaan adsorben buah mengkudu, ini dapat terjadi adsorpsi secara fisika karena setiap partikelpartikel adsorbat yang mendekati permukaan adsorben melalui gaya Van der Waals.

\section{Kesimpulan}

Adsorben dari buah mengkudu (Morinda citrifolia L.) dapat menurunkan nilai parameter mutu minyak jelantah. Namun dari keempat parameter yang digunakan hanya berat jenis yang belum mencapai standar nasional industri. Konsentrasi berat per volume (\%b/b) optimum buah mengkudu yaitu $24 \%$.

\section{Ucapan Terima Kasih}

Penulis mengucapkan terimakasih kepada kepala laboran Agroteknologi FAPERTA dan semua pihak yang telah membantu dalam pelaksanaan penelitian ini.

\section{Referensi}

Abdullah. (2007). Pengaruh gorengan dan intensitas penggorengan terhadap kualitas minyak goreng. Jurnal Pilar Sains, 6(2), 4550 .

Abdullah, N. H., Hasan, S. H., \& Yusoff, N. R. M. (2013). Biodiesel production based on waste cooking oil (WCO). International Journal of Materials Science and Engineering, 1(2), 94-99.

Ahmadi, K. (2009). Kinerja zeolit alam teraktivasi pada penjernihan minyak bekas penggorengan keripik tempe. Jurnal Teknologi Pertanian, 10(2), 136-143.

Aisyah, S., Yulianti, E., \& Fasha, A. G. (2010). Penurunan angka peroksida dan asam lemak bebas (FFA) pada proses bleaching minyak goreng bekas oleh karbon aktif polong buah kelor (moringa oliefera 1.) dengan aktivasi $\mathrm{NaCl}$. Alchemy, 1(2), 53-103.

Barau, F. (2014). Buah mengkudu (morinda citrifolia L.) sebagai pengadsorbsi minyak jelantah. Skripsi. Palu: Universitas Tadulako

Bijanti, R. (2008). Potensi sari buah mengkudu (morinda citrifolia) terhadap kualitas karkas, kadar vitamin C dan kadar malonedialdehide (MDA) dalam darah. Media Kedokteran Hewan, 24(5), 43-48.

Febriansyah, R. (2007). Mempelajari pengaruh penggunaan berulang dan aplikasi adsorben terhadap kualitas minyak dan tingkat penyerapan minyak pada kacang salut. Skripsi. Bogor: Fakultas Teknologi Petanian Institut Pertanian.

Gashaw, A., \& Teshita, A. (2014). Production of biodiesel from waste cooking oil and factors affecting its formation: A review. International Journal of Renewable and Sustainable Energy, 3(5), 92-98.

Gunawan., Triatmo, M., \& Rahayu, A. (2003). Analisis pangan: Penentuan angka peroksida dan asam lemak bebas pada minyak kedelai dengan variasi menggoreng, Jurnal Sains Kimia dan Aplikasi . 5(3), 1-6.

Handoko D. S. P., Triyono., Narsito., \& Dwi, T. (2009). Peningkatan kualitas minyak jelantah menggunakan adsorben H5-NZA dalam reaktor sistem fluid fixed bed. Jurnal Ilmu Dasar, 10( 2), 121-132.

Irwan, M., Thahir, R., \& Kubro, B. S. (2010). Regenerasi minyak jelantah (waste cooking oil) dengan penambahan sari mengkudu. Riset \& Teknologi, 10(1), 56-59

Kusumastuti. (2004). Kinerja zeolit dalam memperbaiki mutu minyak goreng bekas. Jurnal Teknologi dan Pangan, 15(2), 141144.

Muallifah, S. (2009). Penentuan angka asam thiobarbiturat dan angka peroksida pada minyak goreng bekas hasil pemurnian dengan karbon aktif dari biji kelor (moringa oleifera, l). Skripsi. Malang: Fakultas Sains dan Teknologi UIN Maulana Malik Ibrahim. 
Paramitha, A. R. A. (2012). Studi kualitas minyak makanan gorengan pada penggunaan minyak goreng berulang. Skripsi Sarjana pada Universitas Hasanudin Makassar: tidak diterbitkan.

Purwaningsih, S. (2012). Aktivitas antioksidan dan komposisi kimia keong matah merah (cerithidea obtusa). Ilmu Kelautan, 17(1), 39-48.

Sarungu, S. (2010). Pemanfaatan sari buah mengkudu untuk penjernihan minyak jelantah dan analisis kualitasnya. Skripsi Sarjana pada Fakultas Keguruan dan Ilmu pendidikan Universitas Tadulako Palu: tidak diterbitkan.

Wannahari, R., \& Nordin, M. F. N. (2012). Reduction of peroxide value in used palm cooking oil using bagasse adsorbent. American International Journal of Contemporary Research, 2(1), 185-191.

Wibowo, T. (2009). Pengaruh pemberian seduhan kelopak rosela (hibiscus sabdariffa) terhadap kadar trigliserida darah tikus putih (rattus norvegicus). Skripsi Sarjana pada Fakultas Kedokteran Universitas Sebelas Maret: tidak diterbitkan

Widayat. (2007). Studi pengurangan bilangan asam, bilangan peroksida dan absorbansi dalam proses pemurnian minyak goreng bekas dengan zeolit alam aktif. Jurnal Rekayasa Kimia dan Lingkungan, 6(1),
7-12.

Wijayanti, H., Nora, H., \& Amelia, R. (2012). Pemanfaatan arang aktif dari serbuk gergaji kayu ulin untuk meningkatkan kualitas minyak goreng bekas. Konversi, 1(1), 27-33.

Wijayanti, R. (2009). Arang aktif dari ampas tebu sebagai adsorben pada pemurnian minyak goreng bekas. Skripsi Sarjana pada Fakultas Matematika dan Ilmu Pengetahuan Alam Institut Pertanian Bogor: tidak diterbitkan.

Winarni., Sunarto W., \& Mantini, S. (2010). Penetralan dan adsorbsi minyak goreng bekas menjadi minyak goreng layak konsumsi. Jurnal Sains dan Teknologi, 8(1), 46-56.

Winarno, F. G. (1995). Kimia pangan dan gizi. Bandung: Gramedia.

Winarti, S. (2008). Pemanfaatan buah mengkudu (morinda citrifolia) dan kelopak bunga rosela (hibiscus sabdariffa L.) untuk pembuatan fruit leather. Agritech, 28(1), 22-27.

Wulyoadi, S., \& Kaseno. (2004). Pemurnian minyak goreng bekas dengan menggunakan filter membran. Prosiding Seminar Nasional Rekayasa Kimia. Universitas Diponegoro. 